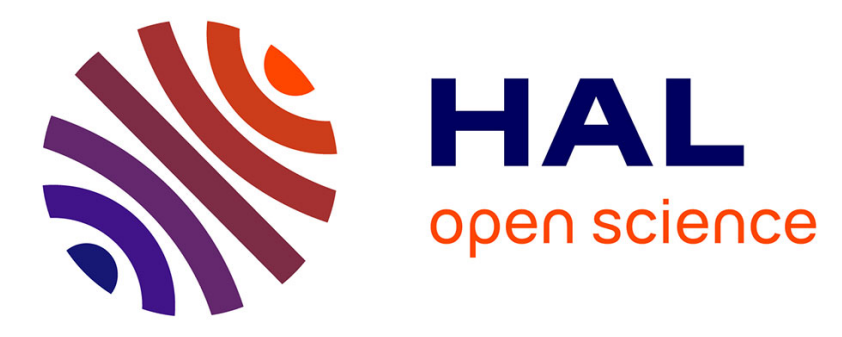

\title{
Control strategy for carbapenemase-producing Enterobacteriaceae in nursing homes: perspectives inspired from three outbreaks
}

C. Legeay, R. Hue, C. Berton, H. Cormier, R. Chenouard, S. Corvec, G. Birgand

\section{To cite this version:}

C. Legeay, R. Hue, C. Berton, H. Cormier, R. Chenouard, et al.. Control strategy for carbapenemaseproducing Enterobacteriaceae in nursing homes: perspectives inspired from three outbreaks. Journal of Hospital Infection, 2019, 101, pp.183 - 187. 10.1016/j.jhin.2018.10.020 • hal-03486731

\section{HAL Id: hal-03486731 https://hal.science/hal-03486731}

Submitted on 20 Dec 2021

HAL is a multi-disciplinary open access archive for the deposit and dissemination of scientific research documents, whether they are published or not. The documents may come from teaching and research institutions in France or abroad, or from public or private research centers.
L'archive ouverte pluridisciplinaire HAL, est destinée au dépôt et à la diffusion de documents scientifiques de niveau recherche, publiés ou non, émanant des établissements d'enseignement et de recherche français ou étrangers, des laboratoires publics ou privés.

\section{(c) (1) $\$$}

Distributed under a Creative Commons Attribution - NonCommerciall 4.0 International 


\section{Control strategy for carbapenemase-producing Enterobacteriaceae in nursing home: Perspectives inspired from three outbreaks.}

Authors: Clément Legeay (PharmD) ${ }^{1}$, Roselyne Hue (PharmD) ${ }^{2}$, Claire Berton (MD) ${ }^{3}$, Hélène Cormier (MD) ${ }^{1}$, Rachel Chenouard (MD) ${ }^{4}$, Stéphane Corvec (PharmD, PhD) ${ }^{5}$, Gabriel Birgand (PharmD, PhD) ${ }^{6,7}$.

${ }^{1}$ Unité de Prévention et de Lutte contre les Infections Nosocomiales, Angers University Hospital, Angers, France.

${ }^{2}$ Infection Control Unit, Centre Hospitalier Loire Vendée Océan, Challans, France

${ }^{3}$ Medical Biology Laboratory, Centre Hospitalier Loire Vendée Océan, Challans, France

${ }^{4}$ Microbiology unit, Angers University Hospital, Angers, France

${ }^{5}$ Microbiology unit, Nantes University Hospital, Nantes, France

${ }^{6}$ CPias Pays de la Loire, Nantes University Hospital, Nantes, France

${ }^{7}$ Health Protection Research Unit, Imperial College London, Royaume-Uni

\section{Corresponding author:}

\section{Dr Clément Legeay}

E.mail: clement.legeay@chu-angers.fr

Phone: +330241355934

Fax: +330241355318

Running title: Carbapenemase outbreaks in nursing homes

Word count: 1535 


\section{Abstract}

We retrospectively assessed three outbreaks of carbapenemase-producing Enterobacteriaceae (CPE) in three nursing homes $(\mathrm{NH})$ in Western France. In all, 10 cases of colonization or infection with CPE were detected upon admission in neighboring hospitals. Antibiotic consumption or high frailty was infrequent among them. $\mathrm{NH}$ should be included in a regional strategy to limit CPE spread. 


\section{Introduction}

French recommendations for the control of carbapenemase-producing Enterobacteriaceae (CPE) in hospitals consist of a strict "search and isolate" strategy. [1]

In nursing homes $(\mathrm{NH})$, the strategy relies on standard precautions with a focus on hand hygiene and excreta management. These measures are based on the assumption that the selection and colonization pressure are lower in $\mathrm{NH}$ than in hospitals, because there is a less susceptible population. However, residents generally stay a long time in $\mathrm{NH}$ during which they often require multiple hospitalizations, most of them leading to antibiotic treatment. These returns between hospitals and $\mathrm{NH}$ may play a role in CPE spread across facilities.[2]

In this study, we describe three episodes of intra-NH spread of CPE detected in neighboring hospitals. These episodes give perspectives to improve the consistency of control measures across settings.

\section{Methods}

Clusters of CPE cases were investigated among three NHs in the Pays de la Loire region (west of France). $\mathrm{NH}_{\mathrm{A}}, \mathrm{NH}_{\mathrm{B}}$ and $\mathrm{NH}_{\mathrm{C}}$ have respectively 408, 127, and 88 beds capacities, with full occupancy. A case was defined as a resident found to be positive with $\mathrm{CPE}$, either on screening or clinical sample.

The retrospective investigation was performed by three investigators ( $C L, R H, G B$ ).

Data collected on CPE cases were: age, gender, length of residency in $\mathrm{NH}$, comorbidities, frailty score, hospitalization records, and antibiotic treatments. Frailty score (GIR score) was calculated by evaluating 8 variables with either $A, B$ or $C$ score. $A=$ can realize this action spontaneously, alone, fully and correctly. $\mathrm{B}=$ can partially realize this 
action. $\mathrm{C}=$ cannot or will not realize this action. Variables assessed are: behavior, orientation in time and space, body toilet, dressing, eating, urinary and faecal elimination, moving from bed to chair on his/her own, walking. Frailty score ranges from 1 (fully dependent) to 6 (fully independent).[3] For each cluster, the geographical situation of cases and the sharing of staff were examined. At the facility level, hand hygiene and the excreta management practices were assessed. Since no hand hygiene $(\mathrm{HH})$ audit was conducted, a surrogate for hand hygiene compliance (AHR index) was calculated based on the ratio between the alcoholic hands rub (AHR) consumption and a theoretical objective of four $\mathrm{HH}$ indications $(3 \mathrm{~mL}$ per friction) per day per resident.

Clonal relatedness among all CPE isolates was investigated by pulsed-field gel electrophoresis (PFGE), performed according to the manufacturer's instructions (BioRad, Marnes-la-coquette, France). PFGE profiles were analyzed using Bionumerics software (Applied Maths, Sint-Martens-Latem, Belgium) and band patterns were analyzed according to the Tenover criteria.[4]

\section{Results}

The first cluster occurred in May 2014. Resident $A_{1}$ was admitted to the local University Hospital (UH) from $\mathrm{NH}_{\mathrm{A}}$. This patient was found positive to OXA-48 producing Klebsiella pneumoniae (Kp-OXA48) in a urine sample, the day after his admission; she had several previous hospitalizations in $\mathrm{UH}$. In July 2014, a resident from $\mathrm{NH}_{\mathrm{A}}\left(\right.$ Patient $\mathrm{A}_{2}$ ) was detected positive for Kp-OXA48 on a screening for colonization through rectal swab performed in UH six days after her admission. Systematic rectal sampling at admission at UH of patients coming from $\mathrm{NH}_{A}$ allowed identifying a third $\left(A_{3}\right)$ and fourth case $\left(A_{4}\right)$, later in 2014 and 2015. Residents $A_{2}, A_{3}$ and $A_{4}$ were hosted in the same building of $\mathrm{NH}_{A}$, but different floors, sharing only night shifts. Resident $A_{1}$ was in a different building. 
Another outbreak was detected in 2014 by UH, with three Kp-OXA48 cases (patients $\mathrm{B}_{1}, \mathrm{~B}_{2}$ and $\left.\mathrm{B}_{3}\right)$ identified. All were admitted from same $\mathrm{NH}\left(\mathrm{NH}_{\mathrm{B}}\right)$. In $\mathrm{NH}_{\mathrm{B}}$, residents $\mathrm{B}_{2}$ and $\mathrm{B}_{3}$ rooms were in the same unit. Resident $B_{1}$ was located at another floor but shared night shift workers with $\mathrm{B}_{2}$ and $\mathrm{B}_{3}$.

No other outbreak was detected through systematic screening of all $\mathrm{NH}$ residents admitted at UH (600 to 700 samples per year between 2014 and 2016).

The last cluster was identified in an 845-bed general hospital $(\mathrm{GH})$. First case $\left(\mathrm{C}_{1}\right)$ was admitted from $\mathrm{NH}_{\mathrm{C}}$ in late 2015. Following this primary case, systematic faecal screening of residents admitted from the $\mathrm{NH}_{\mathrm{C}}$ was organized in the $\mathrm{GH}$. Thirty-three residents were screened from December 2015 to July 2017, identifying two other cases of Kp-OXA48 (patient $\mathrm{C}_{2}$ and $\mathrm{C}_{3}$ ) (Table 1). In $\mathrm{NH}_{\mathrm{C}}$, the three residents were located in the same building. Resident $\mathrm{C}_{1}$ and $\mathrm{C}_{3}$ stayed at the same floor (same staff). Resident $\mathrm{C}_{2}$ stayed at a different floor with a different staff but often visited resident $C_{3}$. The three residents shared the same nursing team during night.

The characteristics of the ten cases involved in the three outbreaks are summarized in Table I; the epidemic curves are represented in Figure 1.

The strains isolated from the three $\mathrm{NH}_{\mathrm{C}}$ residents had the same PFGE profile. Residents in $\mathrm{NH}_{\mathrm{B}}$ and $\mathrm{NH}_{\mathrm{A}}$ also had the same PFGE profile (except $\mathrm{A}_{4}$ ), different from $\mathrm{NH}_{\mathrm{C}}$.

At the facility level, none of the three $\mathrm{NHs}$ was equipped with bedpan washerdisinfector. After excreta elimination in the residents' toilets bedpans used for incontinent residents were taken care of in the residents' room with hand sprayers $\left(\mathrm{NH}_{\mathrm{A}}\right.$ and $\left.\mathrm{NH}_{\mathrm{C}}\right)$, or directly in the sink $\left(\mathrm{NH}_{\mathrm{B}}\right)$. AHR consumption index was respectively $74 \%$, $44 \%$ and $30 \%$ in $\mathrm{NH}_{\mathrm{A}}, \mathrm{NH}_{\mathrm{B}}$ and $\mathrm{NH}_{\mathrm{C}}$ during the outbreak periods. Antibiotic consumption, high frailty or 
incontinence was infrequent among these 10 residents. Five of them had significant hospital stays in the year before CPE detection (Table 1).

\section{Discussion}

Since 2013, repatriated patients from endemic countries have generated two large CPE outbreaks in the two major acute care hospitals of the region.[5] Among colonised/infected cases, some were discharged to $\mathrm{NH}$ without specific precautions. In favourable contexts (low infection control awareness and compliance) CPE slowly spread to several residents. The subsequent hospitalization of these colonized residents insidiously exposed acute care hospitals to a potential outbreak. Out of our 10 patients, five had several hospital stays in the year before being detected positive with CPE. However, none of these hospital stays overlapped with a known CPE carrier stay, except for residents $A_{1}$ and $A_{4}$. In both case, there was one known CPE carrier which was placed under contact precautions upon admission. Weekly screening revealed no secondary case, including these two NH residents during their stay. However, screening can lead to false negative, and the possibility of $\mathrm{UH}$ acquisition of CPE cannot be excluded. Five residents (respectively two in $\mathrm{NH}_{\mathrm{A}}$, one in $\mathrm{NH}_{\mathrm{B}}$ and two in $\mathrm{NH}_{\mathrm{C}}$ ) never had a significant hospital stay before being found CPE-positive. Since there was also no history of travel abroad in any of these cases, $\mathrm{NH}$ acquisition seems highly likely in these residents.

This hypothesis tends to be confirmed by PFGE banding patterns. Indeed, in $\mathrm{NH}_{\mathrm{A}}$, three residents out of four shared the same Kp-OXA48 strain (similar macrorestriction profile), with resident $\mathrm{A}_{4}$ displaying a sporadic strain of unclear origin. In $\mathrm{NH}_{\mathrm{B}}$, all residents shared the same strain, similar to that encountered in $\mathrm{NH}_{\mathrm{A}}$ residents, which was the outbreak strain of neighboring $\mathrm{UH}$. In $\mathrm{NH}_{\mathrm{C}}$, all residents shared the same strains, although different from $\mathrm{NH}_{\mathrm{A}}, \mathrm{NH}_{\mathrm{B}}$ and $\mathrm{UH}$. This strain was later confirmed as the outbreak strain from the closest University Hospital. $\mathrm{NH}_{\mathrm{A}}, \mathrm{NH}_{\mathrm{B}}$ and $\mathrm{UH}$ are within a 30 kilometers radius, whereas 
$\mathrm{NH}_{\mathrm{C}}$ is seven kilometers away from $\mathrm{GH}(\mathrm{GH}$ is $150 \mathrm{~km}$ from $\mathrm{UH})$. These data tend to confirm the risk of intra-institution spread of multidrug-resistant Enterobacteriaceae (MRE) in the geographical area surrounding major acute care hospitals.

The role of $\mathrm{NH}$ in antimicrobial resistance spread has been previously demonstrated.[2,6] CPE spread in $\mathrm{NH}$, with potential impact of surrounding hospitals has already been described, even in low prevalence countries.[7] In our experience, NHs are exposed to the risk of MRE carriers, being directly downstream of acute care hospitals. Despite a theoretical lower selective and colonization pressure in these settings, the spread of MRE is facilitated by the lack of standard infection control precautions. None of the three NHs consumed enough AHR consumption to comply with four hand hygiene events per resident per day. Excreta management involved basins cleaned in residents' rooms, increasing the risk for environmental contamination with fecal microorganisms.

In a national context of strict "search and isolate" strategy in hospitals, even if the reservoir and the transmissibility in $\mathrm{NH}$ seem low, one unknown carrier admitted in acute care from $\mathrm{NH}$ can generate an invisible outbreak of carriage. If not rapidly and accurately controlled, this dissemination generates major financial consequences and a subsequent infectious risk at the population scale.[9] Successful interventions show that national and local strategies need to be consistent across the entire patient pathway, from acute care to $\mathrm{NH}$.[9] A lapse in one link may have consequences on another. Despite the fact that hospital guidelines cannot be transposed to NHs, some compromises may be found. A first step would be to better understand the epidemiology of CPE in NH. Point prevalence surveys for CPE carriage need to be performed through the different healthcare sectors (from acute care to nursing home) for a better understanding of the regional epidemiology. Secondly, the level of standard precaution in $\mathrm{NH}$ must be raised with external help from infection control teams. Finally, identification and screening of resident coming from $\mathrm{NH}$ hosting $\mathrm{CPE}$ patients at hospital admission might be considered. Our study tends to confirm the conclusions from 
recent guidelines [10]. NHs have to be considered as high risk units where isolation or screening should not be encouraged, but where information regarding MRE should be diffused an adherence to standard precautions prompted.

\section{Acknowledgements:}

We thank V. Borriello, B. Gravouille, F. Prod'homme, and F. Knapp for their help in the data collection.

Conflict of interest: the authors declare no conflict of interest regarding this manuscript Financial support: None reported

Contribution: All authors have contributed significantly to this work, read and approved the manuscript. 


\section{References}

[1] Lepelletier D, Berthelot P, Lucet JC, Fournier S, Jarlier V, Grandbastien B; National Working Group. French recommendations for the prevention of "emerging extensively drugresistant bacteria" (eXDR) cross-transmission. J Hosp Infect 2015;90:186-195.

[2] van den Dool C, Haenen A, Leenstra T, Wallinga J. The Role of Nursing Homes in the Spread of Antimicrobial Resistance Over the Healthcare Network. Infect Control Hosp Epidemiol 2016;37:761-767.

[3] Syndicat National de Gérontologie Clinique. AGGIR: guide pratique pour la codification des variables, principaux porfils des groupes iso-ressources. Revue Gériatrie 1994;19:249-260.

[4] Tenover FC, Arbeit RD, Goering RV, Mickelsen PA, Murray BE, Persing DH, et al.. Interpreting chromosomal DNA restriction patterns produced by pulsed-field gel electrophoresis: criteria for bacterial strain typing. J Clin Microbiol 1995;33:2233-2239.

[5] Semin-Pelletier B, Cazet L, Bourigault C, Juvin ME, Boutoille D, Raffi F, et al. Challenges of controlling a large outbreak of OXA-48 carbapenemase-producing Klebsiella pneumoniae in a French university hospital. J Hosp Infect 2015;89:248-253.

[6] D'Agata EMC, Habtemariam D, Mitchell S. Multidrug-Resistant Gram-Negative Bacteria: Inter- and Intradissemination Among Nursing Homes of Residents With Advanced Dementia. Infect Control Hosp Epidemiol 2015;36:930-935.

[7] Weterings V, Zhou K, Rossen JW, van Stenis D, Thewessen E, Kluytmans J,, et al. An outbreak of colistin-resistant Klebsiella pneumoniae carbapenemase-producing Klebsiella pneumoniae in the Netherlands (July to December 2013), with inter-institutional spread. Eur J Clin Microbiol Infect Dis 2015;34:1647-1655.

[8] Birgand G, Leroy C, Nerome S, Luong Nguyen LB, Lolom I, Armand-Lefevre L,, et al. Costs associated with implementation of a strict policy for controlling spread of highly resistant microorganisms in France. BMJ Open 2016;6:e009029 
[9] Ben-David D, Masarwa S, Fallach N, Temkin E, Solter E, Carmeli Y, et al. Success of a National Intervention in Controlling Carbapenem-Resistant Enterobacteriaceae in Israel's Long-Term Care Facilities. Clin Infect Dis 2018 (in press)

[10] Wilson AP, Livermore DM, Otter JA, Warren RE, Jenks P, Enoch DA et al. Prevention and control of multi-drug-resistant Gram-negative bacteria: recommendations from a Joint Working Party. J Hosp Infect 2016;92 Suppl1:S1-44. 
Table 1. Characteristics of the 10 Resident CPE carriers identified during three outbreaks in the three different nursing homes

\begin{tabular}{|c|c|c|c|c|c|c|c|c|}
\hline Resident & Age & Gender & CPE strain & $\begin{array}{l}\text { Date of 1st } \\
\text { CPE positive } \\
\text { sample }\end{array}$ & $\begin{array}{c}\text { Delay between } \\
\text { admission and } \\
\text { positive } \\
\text { sample (days) }\end{array}$ & $\begin{array}{l}\text { Duration } \\
\text { of NH stay } \\
\text { (months) }\end{array}$ & $\begin{array}{c}\text { Antibiotic } \\
\text { treatment the } 3 \\
\text { months before } \\
\text { CPE } \\
\text { identification }\end{array}$ & $\begin{array}{l}\text { Frailty } \\
\text { score }\end{array}$ \\
\hline A1 & 91 & $\mathrm{~F}$ & KP-OXA48 & $\begin{array}{l}\text { Urine } \\
27 / 05 / 2014\end{array}$ & 1 & 18 & NO & 3 \\
\hline $\mathrm{A} 2$ & 74 & $\mathrm{~F}$ & KP-OXA48 & $\begin{array}{c}\text { Rectal swab } \\
01 / 07 / 2014\end{array}$ & 6 & 145 & NO & 5 \\
\hline A3 & 77 & $M$ & $\begin{array}{l}\text { KP-OXA48 } \\
\text { and EC- } \\
\text { OXA48 }\end{array}$ & $\begin{array}{c}\text { Rectal swab } \\
15 / 10 / 2014\end{array}$ & 1 & 57 & NO & 5 \\
\hline A4 & 66 & M & $\begin{array}{l}\text { KP-OXA48 } \\
\text { and EC- } \\
\text { OXA48 }\end{array}$ & $\begin{array}{l}\text { Rectal swab } \\
12 / 08 / 2015\end{array}$ & 1 & 66 & NO & 4 \\
\hline B1 & 90 & M & KP-OXA48 & $\begin{array}{c}\text { Urine } \\
07 / 06 / 2014\end{array}$ & 0 & 28 & YES & 4 \\
\hline B2 & 93 & $M$ & KP-OXA48 & $\begin{array}{c}\text { Urine } \\
21 / 07 / 2014\end{array}$ & 0 & 3 & NO & 3 \\
\hline B3 & 96 & $F$ & KP-OXA48 & $\begin{array}{c}\text { Urine } \\
18 / 02 / 2016\end{array}$ & 5 & 35 & NO & 3 \\
\hline $\mathrm{C} 1$ & 84 & $\mathrm{~F}$ & KP-OXA48 & $\begin{array}{c}\text { Urine } \\
11 / 12 / 2015\end{array}$ & 0 & 123 & YES & 2 \\
\hline $\mathrm{C} 2$ & 90 & $M$ & KP-OXA48 & $\begin{array}{l}\text { Rectal swab } \\
16 / 01 / 2016\end{array}$ & 9 & 60 & NO & 4 \\
\hline C3 & 92 & $\mathrm{~F}$ & $\begin{array}{l}\text { KP-OXA48 } \\
\text { and EC- } \\
\text { OXA48 }\end{array}$ & $\begin{array}{l}\text { Rectal swab } \\
08 / 11 / 2016\end{array}$ & 7 & 140 & NO & 3 \\
\hline
\end{tabular}

Abbreviations: KP, Klebsiella pneumoniae; EC, Escherichia coli; CPE, carbapenemase producing Enterobacteriaceae; $\mathrm{NH}$, nursing home; F, female; M, male 


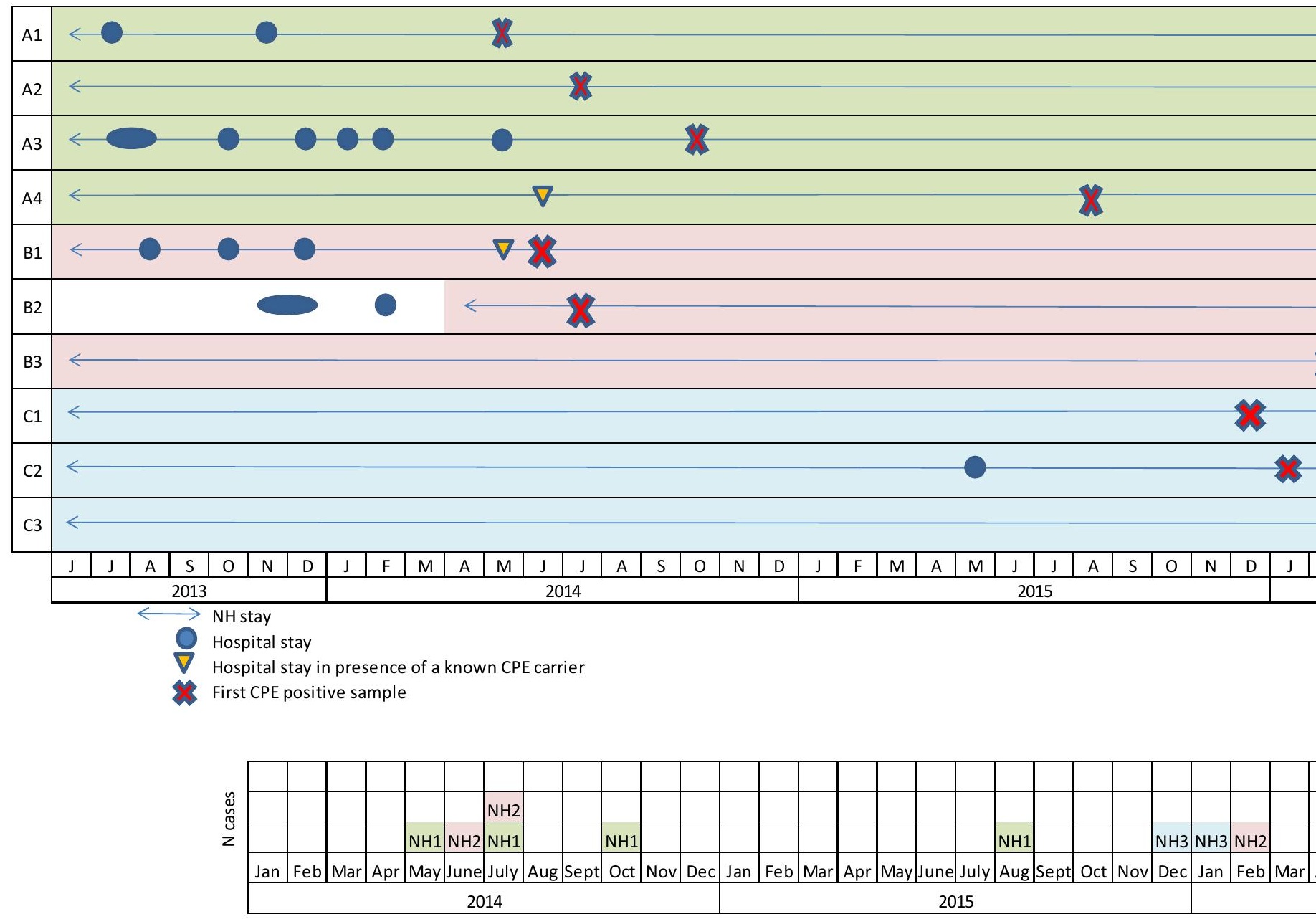

Figure 1: Synoptic table and epidemic curve of CPE colonized residents in NH1 (green), NH2 (red) and NH3 (blue). Hospital stays longer than $48 \mathrm{~h}$ are indicated each months preceding first detection of CPE. Hospitalization in presence of a known CPE carrier is marked by a yellow triangle. Red crosses indicate month of first CPE detection. 